Conclusion: Regardless of previous biologic DMARD failure, pts treated with UPA15 or UPA30 achieved a higher rate of remission or LDA measured by various disease activity measures vs PBO at Wk 24; higher rates of response were observed in most of the remission and LDA measures with UPA30 vs ADA in non-biologic DMARD-IR pts. Among pts who did or did not achieve MDA criteria at Wk 24, a greater proportion of UPA-treated pts achieved physician derived measures such as SJC $\leq 1, \mathrm{PASI} \leq 1$ or BSA-Ps $\leq 3 \%$, and $\mathrm{LEI} \leq 1$. REFERENCES:

[1] Mclnnes IB, et al. Ann Rheum Dis, 2020; 79:12.

[2] Genovese MC, et al. Ann Rheum Dis, 2020; 79:139.

Table 1. Proportion of Patients Achieving Remission and LDA Measures at Week 24

\begin{tabular}{|c|c|c|c|c|c|c|c|}
\hline \multirow[b]{2}{*}{$\begin{array}{l}\text { Endpoint, } \\
\mathrm{n}(\%)\end{array}$} & \multicolumn{4}{|c|}{ SELECT-PsA 1} & \multicolumn{3}{|c|}{ SELECT-PsA 2} \\
\hline & $\begin{array}{l}\text { PBO } \\
\mathrm{N}=423\end{array}$ & $\begin{array}{c}\text { ADA 40mg } \\
\text { EOW } \\
\mathrm{N}=429\end{array}$ & $\begin{array}{c}\text { UPA } \\
\text { 15mg QD } \\
\mathrm{N}=429\end{array}$ & $\begin{array}{c}\text { UPA } \\
\text { 30mg QD } \\
\mathrm{N}=423\end{array}$ & $\begin{array}{c}\text { PBO } \\
\mathrm{N}=212\end{array}$ & $\begin{array}{c}\text { UPA 15mg } \\
\text { QD } \\
N=211\end{array}$ & $\begin{array}{c}\text { UPA } \\
\text { 30mg QD } \\
\mathrm{N}=218\end{array}$ \\
\hline MDA & 52 (12.3) & $143(33.3)$ & $\begin{array}{c}157 \\
(36.6)^{*, \#}\end{array}$ & $\begin{array}{c}192 \\
(45.4)^{*, \dagger, \#}\end{array}$ & $6(2.8)$ & $\begin{array}{c}53 \\
(25.1)^{*, \#}\end{array}$ & $\begin{array}{c}63 \\
(28.9)^{*, \#}\end{array}$ \\
\hline $\begin{array}{l}\geq 6 \text { VLDA } \\
\quad \text { components }\end{array}$ & $25(5.9)$ & $90(21.0)$ & $\begin{array}{c}105 \\
(24.5) \text { * }\end{array}$ & $\begin{array}{c}134 \\
(31.7)^{*, \dagger}\end{array}$ & $3(1.4)$ & $\begin{array}{c}26 \\
(12.3)^{*}\end{array}$ & $\begin{array}{c}44 \\
(20.2)^{*}\end{array}$ \\
\hline VLDA & $11(2.6)$ & $62(14.5)$ & $\begin{array}{c}55 \\
(12.8)\end{array}$ & $\begin{array}{c}72 \\
(17.0)\end{array}$ & $(1.4)$ & $\begin{array}{c}16 \\
(7.6) \text { * }\end{array}$ & $\begin{array}{c}21 \\
(9.6)\end{array}$ \\
\hline DAPS & $9(2.1)$ & 43( & $\begin{array}{c}47 \\
(11.0)^{*}\end{array}$ & $\begin{array}{c}79 \\
(18.7)^{*+\dagger}\end{array}$ & $1(0.5)$ & $\begin{array}{c}15 \\
(7.1)^{*}\end{array}$ & $\begin{array}{c}28 \\
(12.8)\end{array}$ \\
\hline DAPS & $70(1$ & 198 & $\begin{array}{c}204 \\
(47.6)\end{array}$ & $\begin{array}{c}235 \\
(55.6)^{*, \dagger}\end{array}$ & $14(6.6)$ & $\begin{array}{c}73 \\
(34.6)\end{array}$ & $\begin{array}{c}91 \\
(41.7) \text { * }\end{array}$ \\
\hline PASDAS REM & $12(2.8)$ & $51(11.9)$ & $\begin{array}{c}60 \\
(14.0)^{*}\end{array}$ & $\begin{array}{c}91 \\
(21.5)^{*}+\end{array}$ & $4(1.9)$ & $\begin{array}{c}20 \\
(9.5) \text { * }\end{array}$ & $\begin{array}{c}31 \\
(14.2)^{*}\end{array}$ \\
\hline PASDAS LDA & $63(14.9)$ & $168(39.2)$ & $\begin{array}{c}195 \\
(45.5)^{*}\end{array}$ & $\begin{array}{c}211 \\
(49.9)^{*, \dagger}\end{array}$ & $9(4.2)$ & $\begin{array}{c}69 \\
(32.7) \text { * }\end{array}$ & $\begin{array}{c}82 \\
(37.6) \text { * }\end{array}$ \\
\hline
\end{tabular}

${ }^{*} \mathrm{P} \leq 0.05$ for UPA 15 and UPA30 vs PBO; $\uparrow P \leq 0.05$ for UPA30 vs ADA; "Statistically significant in the multiplicity-controlled analysis.MDA (5/7) and VLDA (7/7): TJC $\leq 1$; SJC $\leq 1$; PASI $\leq 1$ or BSA-Psoriasis $\leq 3 \%$; Patient's Assessment of Pain NRS $\leq 1.5$; PtGA-Disease Activity NRS $\leq 2.0$; HAQ-DI score $\leq 0.5$; and tender entheseal points $\leq 1$.DAPSA REM $\leq 4$; DAPSA LDA $\leq$ 14.PASDAS REM $\leq 1.9$; PASDAS LDA $\leq 3.2$.
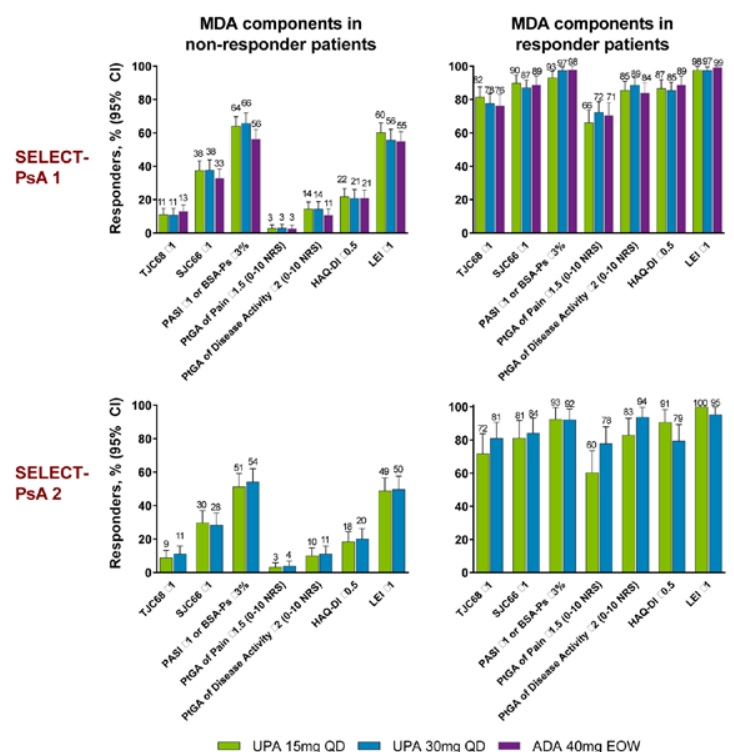

UPA $15 \mathrm{mg}$ QD $=$ UPA $30 \mathrm{mg} Q \mathrm{QD}=\mathrm{ADA} 40 \mathrm{mg}$ EOW

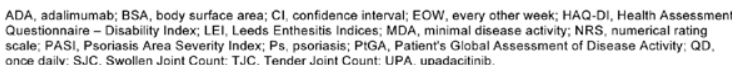

Figure 1

Acknowledgements: AbbVie and the authors thank the patients, study sites, and investigators who participated in this clinical trial. AbbVie, Inc was the study sponsor, contributed to study design, data collection, analysis \& interpretation, and to writing, reviewing, and approval of final version. No honoraria or payments were made for authorship. Medical writing support was provided by Ramona Vladea, PhD of AbbVie Inc.

Disclosure of Interests: Philip J Mease Speakers bureau: AbbVie, Amgen, Boehringer Ingelheim, Bristol Myers, Celgene, Galapagos, Gilead, GlaxoSmithKline, Janssen, Lilly, Merck, Novartis, Pfizer, Sun Pharma, and UCB. Consultant of: AbbVie, Amgen, Boehringer Ingelheim, Bristol Myers, Celgene, Galapagos, Gilead, GlaxoSmithKline, Janssen, Lilly, Merck, Novartis,
Pfizer, Sun Pharma, and UCB., Grant/research support from: AbbVie, Amgen, Boehringer Ingelheim, Bristol Myers, Celgene, Galapagos, Gilead, GlaxoSmithKline, Janssen, Lilly, Merck, Novartis, Pfizer, Sun Pharma, and UCB. Arthur Kavanaugh Consultant of: AbbVie Inc., Amgen, Astra-Zeneca, BMS, Celgene, Centocor-Janssen, Pfizer, Roche, and UCB, Grant/research suppor from: AbbVie Inc., Amgen, Astra-Zeneca, BMS, Celgene, Centocor-Janssen, Pfizer, Roche, and UCB, Dafna D Gladman Grant/research support from: AbbVie, Amgen, Bristol-Myers Squibb, Celgene Corporation, Eli Lilly, Galapagos, Gilead, Janssen, Novartis, Pfizer Inc, and UCB, Oliver FitzGerald Speakers bureau: AbbVie, Amgen, BMS, Celgene, Janssen, Lilly, Novartis, Pfizer and UCB, Consultant of: AbbVie, Amgen, BMS, Celgene, Janssen, Lilly, Novartis, Pfizer and UCB, Grant/research support from: AbbVie, Amgen, BMS, Celgene Janssen, Lilly, Novartis, Pfizer and UCB, Enrique Soriano Speakers bureau: AbbVie, Amgen, Bristol Myers, Celgene, Janssen, Lilly, Novartis, Pfizer, Roche Sanofi, and UCB, Consultant of: AbbVie, Amgen, Bristol Myers, Celgene, Janssen, Lilly, Novartis, Pfizer, Roche, Sanofi, and UCB, Grant/research support from: AbbVie, Amgen, Bristol Myers, Celgene, Janssen, Lilly, Novartis, Pfizer, Roche, Sanofi, and UCB, Peter Nash Speakers bureau: AbbVie, BMS, Roche, Pfizer, Janssen, Amgen, Sanofi-Aventis, UCB, Eli Lilly, Novartis, and Celgene, Consultant of: AbbVie, BMS, Roche, Pfizer, Janssen, Amgen, Sanofi-Aventis, UCB, Eli Lilly, Novartis, and Celgene, Grant/research support from: AbbVie BMS, Roche, Pfizer, Janssen, Amgen, Sanofi-Aventis, UCB, Eli Lilly, Novartis, and Celgene, Dai Feng Shareholder of: AbbVie, Employee of: AbbVie, Apinya Lertratanakul Shareholder of: AbbVie, Employee of: AbbVie, Kevin Douglas Shareholder of: AbbVie, Employee of: AbbVie, Ralph Lippe Shareholder of: AbbVie, Employee of: AbbVie, Laure Gossec Consultant of: AbbVie,Amgen Biogen, Celgene, Janssen, Lilly, Novartis, Pfizer, Samsung, Sanofi, UCB, Grant/research support from: Lilly, Pfizer, and Sandoz.

DOI: 10.1136/annrheumdis-2021-eular.574

\section{AB0530 $\quad$ EFFECT OF SKIN SYMPTOMS ON DISEASE IMPACT IN PATIENTS WITH PSORIATIC ARTHRITIS RECEIVING THE IL-12/23 INHIBITOR USTEKINUMAB OR TNF INHIBITORS IN THE REAL-WORLD PSABIO STUDY}

J. S. Smolen ${ }^{1}$, T. Korotaeva ${ }^{2}$, M. Nurmohamed ${ }^{3}$, S. Siebert ${ }^{4}$, P. Bergmans ${ }^{5}$, K. De Vlam $^{6}$, E. Gremese ${ }^{7}$, B. Joven-Ibáñez ${ }^{8}$, W. Noel ${ }^{9}$, P. Sfikakis ${ }^{10}$, E. Theander ${ }^{11}$, L. Gossec ${ }^{12,13} .{ }^{1}$ Medical University of Vienna, Division of Rheumatology, Department of Medicine III, Vienna, Austria; ${ }^{2}$ VA Nasonova Research Institute of Rheumatology, Department of Spondyloarthritis and Psoriatic Arthritis, Moscow, Russian Federation; ${ }^{3}$ Reade and VU University Medical Center, Department of Rheumatology, Amsterdam, Netherlands; ${ }^{4}$ University of Glasgow, Institute of Infection Immunity and Inflammation, Glasgow, United Kingdom; ${ }^{5}$ Janssen-Cilag BV, Biostatistics, Breda, Netherlands; ${ }^{6}$ University Hospitals Leuven, Division of Rheumatology, Leuven, Belgium; ${ }^{7}$ Catholic University of the Sacred Heart Fondazione Policlinico A Gemelli IRCCS, Rome, Italy; ${ }^{8}$ University Hospital 12 de Octubre, Department of Rheumatology, Madrid, Spain; ${ }^{9}$ Janssen Pharmaceutica NV, Medical Affairs, Beerse, Belgium; ${ }^{10}$ National and Kapodistrian University of Athens Medical School, First Department of Propaedeutic and Internal Medicine, Athens, Greece; ${ }^{11}$ Janssen-Cilag AB, Medical Affairs, Solna, Sweden; ${ }^{12}$ Sorbonne University, INSERM, Pierre Louis Institute of Epidemiology and Public Health, Paris, France; ${ }^{13}$ Pitié-Salpêtrière Hospital, AP-HP, Department of Rheumatology, Paris, France

Background: Psoriatic arthritis (PsA) is characterised by musculoskeletal symptoms, and patients (pts) with PsA usually experience psoriasis concurrently. Real-world data reflecting impact of skin symptoms on PSA disease burden are limited.

Objectives: Analyse effectiveness of ustekinumab (UST) and tumour necrosis factor inhibitor (TNFi) therapy on extent of skin involvement, and the impact this has on PsA disease burden and drug persistence.

Methods: PsABio (NCT02627768) is a prospective, observational study of 1st/2nd/3rd-line UST or TNFi treatment in PsA in 8 European countries. Extent of skin involvement was categorised as body surface area (BSA): clear/almost clear; $<3 \%$ but not clear/almost clear; $3-10 \%$; or $>10 \%$. Pt-reported disease impact was evaluated by PSAID-12, including assessment of two skin-related domains (D): D3 (skin problems, including itching) and D10 (embarrassment and/or shame because of appearance). Estimated persistence at 1 year was assessed across baseline (BL) BSA categories

Results: At BL, significantly more pts receiving UST than TNFi had BSA $>10 \%$ (Figure 1). BL disease impact (PSAID-12) was worse in pts with BSA $>10 \%$ than $<3 \%$ in D3, D10 and total (non-overlapping $95 \%$ Cls suggest significance) (Table 1). BSA improved from BL to 1 year with both treatments. At 1 year, $64 \%$ of pts in both groups had clear/almost clear skin and only $3 \%$ had BSA $>10 \%$ (Figure 1). At 1 year, both treatments significantly reduced disease impact (PsAID12 total), and D3 and D10 scores, irrespective of BL BSA category, but most markedly in pts with higher BL BSA (Table 1). Worse BL psoriasis was generally associated with longer persistence for both treatments; however, at 1 year, pts 
with BSA $>10 \%$ had significantly shorter persistence with TNFi (mean $[95 \% \mathrm{Cl}$ ]: 361 [336; 387] days) than with UST (410 [394; 426] days).

Conclusion: In PsA, interleukin-12/23 inhibition (UST) and TNFi therapy in routine care rapidly and substantially reduced extent of skin involvement and related disease impact. Pts with highest BL skin involvement had significantly longer drug persistence with UST than with TNFi. Together, PsABio data suggest that successful treatment of skin involvement in PsA with biologics reduces disease burden and may improve persistence, especially in pts with worse BL psoriasis.

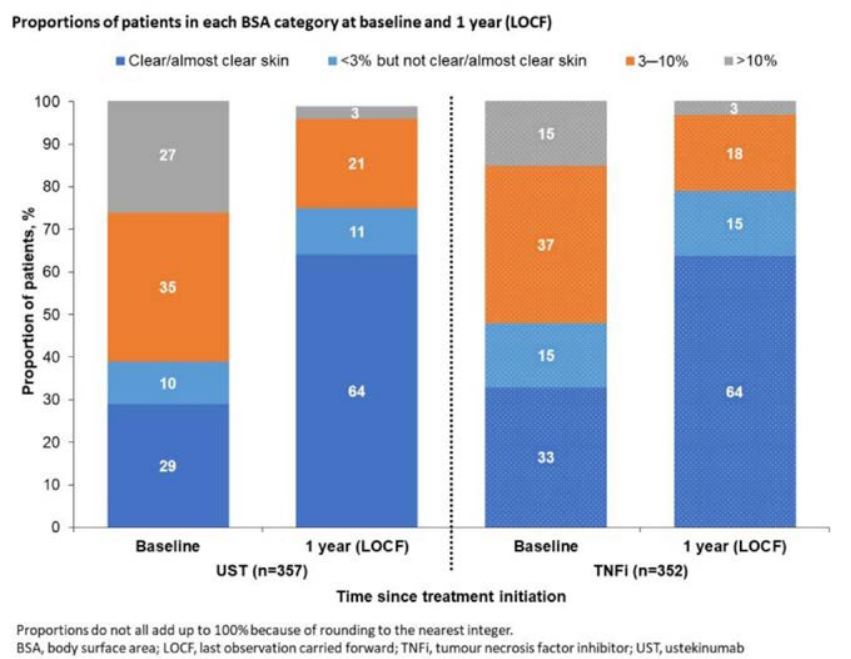

Figure 1

Table 1. PsAID-12 scores at BL and change from BL scores at 6 months and 1 year, by BL BSA category

\begin{tabular}{|c|c|c|c|c|c|c|}
\hline \multirow{2}{*}{$\begin{array}{l}\text { Mean } \\
(95 \% \mathrm{Cl})\end{array}$} & \multicolumn{2}{|c|}{$\begin{array}{c}\text { Domain } 3 \\
\text { (skin problems, including } \\
\text { itching) }\end{array}$} & \multicolumn{2}{|c|}{$\begin{array}{c}\text { Domain } 10 \\
\text { (embarrassment and/or } \\
\text { shame because of } \\
\text { appearance) }\end{array}$} & \multicolumn{2}{|c|}{$\begin{array}{c}\text { Total } \\
\text { PsAID-12 }\end{array}$} \\
\hline & UST & TNFi & UST & TNFi & UST & TNFi \\
\hline \multicolumn{7}{|c|}{ PsAID-12 score at BL by BL BSA } \\
\hline$<3 \%$ & $\begin{array}{c}4.2 \\
(3.7 ; 4.8)\end{array}$ & $\begin{array}{c}3.1 \\
(2.7 ; 3.6)\end{array}$ & $\begin{array}{c}3.9 \\
(3.3 ; 4.4)\end{array}$ & $\begin{array}{c}3.1 \\
(2.6 ; 3.6)\end{array}$ & $\begin{array}{c}5.7 \\
(5.3 ; 6.0)\end{array}$ & $\begin{array}{c}5.0 \\
(4.6 ; 5.3)\end{array}$ \\
\hline $3-10 \%$ & $\begin{array}{c}6.4 \\
(5.9 ; 6.8)\end{array}$ & $\begin{array}{c}5.8 \\
(5.3 ; 6.3)\end{array}$ & $\begin{array}{c}4.1 \\
(3.5 ; 4.7)\end{array}$ & $\begin{array}{c}4.5 \\
(3.9 ; 5.1)\end{array}$ & $\begin{array}{c}5.4 \\
(5.1 ; 5.8)\end{array}$ & $\begin{array}{c}5.8 \\
(5.4 ; 6.1)\end{array}$ \\
\hline$>10 \%$ & $\begin{array}{c}7.9 \\
(7.5 ; 8.3)\end{array}$ & $\begin{array}{c}6.7 \\
(6.0 ; 7.5)\end{array}$ & $\begin{array}{c}6.1 \\
(5.4 ; 6.8)\end{array}$ & $\begin{array}{c}5.8 \\
(4.8 ; 6.8)\end{array}$ & $\begin{array}{c}6.2 \\
(5.7 ; 6.6)\end{array}$ & $\begin{array}{c}6.1 \\
(5.6 ; 6.7)\end{array}$ \\
\hline \multicolumn{7}{|c|}{ Change from BL in PsAID-12 score at 6 months by BL BSA } \\
\hline$<3 \%$ & $\begin{array}{c}-1.5 \\
(-2.1 ;-0.9)\end{array}$ & $\begin{array}{c}-0.8 \\
(-1.3 ;-0.3)\end{array}$ & $\begin{array}{c}-1.5 \\
(-2.0 ;-0.9)\end{array}$ & $\begin{array}{c}-1.2 \\
(-1.6 ;-0.7)\end{array}$ & $\begin{array}{c}-1.6 \\
(-2.0 ;-1.2)\end{array}$ & $\begin{array}{c}-1.9 \\
(-2.2 ;-1.5)\end{array}$ \\
\hline $3-10 \%$ & $\begin{array}{c}-3.2 \\
(-3.8 ;-2.7)\end{array}$ & $\begin{array}{c}-2.4 \\
(-3.0 ;-1.9)\end{array}$ & $\begin{array}{c}-1.9 \\
(-2.5 ;-1.3)\end{array}$ & $\begin{array}{c}-2.0 \\
(-2.5 ;-1.5)\end{array}$ & $\begin{array}{c}-2.0 \\
(-2.4 ;-1.6)\end{array}$ & $\begin{array}{c}-2.4 \\
(-2.8 ;-2.0)\end{array}$ \\
\hline$>10 \%$ & $\begin{array}{c}-4.2 \\
(-4.9 ;-3.6)\end{array}$ & $\begin{array}{c}-2.5 \\
(-3.2 ;-1.9)\end{array}$ & $\begin{array}{c}-2.9 \\
(-3.5 ;-2.2)\end{array}$ & $\begin{array}{c}-1.6 \\
(-2.4 ;-0.8)\end{array}$ & $\begin{array}{c}-2.4 \\
(-2.8 ;-2.0)\end{array}$ & $\begin{array}{c}-2.2 \\
(-2.7 ;-1.7)\end{array}$ \\
\hline \multicolumn{7}{|c|}{ Change from BL in PsAID-12 score at 1 year (LOCF) by BL BSA } \\
\hline$<3 \%$ & $\begin{array}{c}-1.5 \\
(-2.1 ;-0.9)\end{array}$ & $\begin{array}{c}-0.8 \\
(-1.3 ;-0.3)\end{array}$ & $\begin{array}{c}-1.6 \\
(-2.2 ;-1.1)\end{array}$ & $\begin{array}{c}-1.2 \\
(-1.7 ;-0.7)\end{array}$ & $\begin{array}{c}-1.6 \\
(-2.0 ;-1.2)\end{array}$ & $\begin{array}{c}-1.9 \\
(-2.3 ;-1.5)\end{array}$ \\
\hline $3-10 \%$ & $\begin{array}{c}-3.5 \\
(-4.0 ;-2.9)\end{array}$ & $\begin{array}{c}-3.2 \\
(-3.7 ;-2.7)\end{array}$ & $\begin{array}{c}-2.0 \\
(-2.6 ;-1.4)\end{array}$ & $\begin{array}{c}-2.5 \\
(-3.0 ;-2.0)\end{array}$ & $\begin{array}{c}-2.2 \\
(-2.6 ;-1.7)\end{array}$ & $\begin{array}{c}-3.0 \\
(-3.4 ;-2.6)\end{array}$ \\
\hline$>10 \%$ & $\begin{array}{c}-4.9 \\
(-5.5 ;-4.3)\end{array}$ & $\begin{array}{c}-3.1 \\
(-4.0 ;-2.3)\end{array}$ & $\begin{array}{c}-3.5 \\
(-4.2 ;-2.8)\end{array}$ & $\begin{array}{c}-2.7 \\
(-3.7 ;-1.8)\end{array}$ & $\begin{array}{c}-2.9 \\
(-3.4 ;-2.4)\end{array}$ & $\begin{array}{c}-2.9 \\
(-3.5 ;-2.2)\end{array}$ \\
\hline
\end{tabular}

PsAID-12 total score $\leq 4$ is considered a patient-acceptable symptom state.BL, baseline; BSA, body surface area; $\mathrm{Cl}$, confidence interval; LOCF, last observation carried forward; PsAID-12, 12-item Psoriatic Arthritis Impact of Disease questionnaire; TNFi, tumour necrosis factor inhibitor; UST, ustekinumab

Acknowledgements: This study was funded by Janssen.

Disclosure of Interests: Josef S. Smolen Speakers bureau: AbbVie, Amgen, AstraZeneca, Astro, Bristol-Myers Squibb, Celgene, Celltrion, Chugai, Gilead, ILTOO, Janssen, Lilly, MSD, Novartis- Sandoz, Pfizer, Roche, Samsung, Sanofi, UCB, Grant/research support from: AbbVie, AstraZeneca, Lilly, Novartis, Roche, Tatiana Korotaeva Speakers bureau: AbbVie, Amgen, Biocad, Janssen, Lilly, MSD, Novartis, Novartis-Sandoz, Pfizer, UCB, Consultant of: AbbVie, Amgen, Biocad, Janssen, Lilly, MSD, Novartis, Novartis-Sandoz, Pfizer, UCB, Grant/ research support from: Pfizer, Michael Nurmohamed Speakers bureau: AbbVie, Bristol-Myers Squibb, Celgene, Eli Lilly, Janssen, Menarini, MSD, Mundipharma, Pfizer, Roche, Sanofi, UCB, Consultant of: AbbVie, Bristol-Myers Squibb, Celgene, Eli Lilly, Galapagos, Janssen, Menarini, MSD, Mundipharma, Pfizer, Roche, Sanofi, UCB, Grant/research support from: AbbVie, Bristol-Myers Squibb,
Celgene, Eli Lilly, Galapagos, Gilead, Janssen, Menarini, MSD, Mundipharma, Pfizer, Roche, Sanofi, UCB, Stefan Siebert Speakers bureau: AbbVie, Amgen (previously Celgene), Biogen, Janssen, Novartis, UCB, Consultant of: AbbVie Janssen, UCB, Grant/research support from: Amgen (previously Celgene), Boehringer Ingelheim, Bristol-Myers Squibb, GSK, Janssen, Novartis, Pfizer UCB, Paul Bergmans Shareholder of: Johnson \& Johnson, Employee of: Janssen, Kurt de Vlam Speakers bureau: AbbVie, Amgen, Eli Lilly, Novartis, UCB, Paid instructor for: Amgen, Galapagos, UCB, Consultant of: Eli Lilly, Galapagos, Johnson \& Johnson, Novartis, UCB, Grant/research support from: Celgene, Elisa Gremese: None declared., Beatriz Joven-lbáñez Speakers bureau: AbbVie, Celgene, Janssen, Novartis, MSD, Pfizer, Wim Noel Employee of: Janssen, Petros Sfikakis Consultant of: AbbVie, Actelion, Boehringer Ingelheim, Enorasis, Farmaserv-Lilly, Genesis, Gilead, MSD, Novartis, Pfizer, UCB, Grant/research support from: AbbVie, Amgen, Boehringer Ingelheim, Faran, Janssen, Pfizer, Roche Elke Theander Employee of: Janssen, Laure Gossec Consultant of: AbbVie, Amgen, Bioepis, Biogen, Bristol-Myers Squibb, Celgene, Galapagos, Gilead Janssen, Lilly, Novartis, Pfizer, Samsung Sanofi-Aventis, UCB, Grant/research support from: Amgen, Galapagos, Janssen, Lilly, Pfizer, Sandoz, Sanofi. DOI: 10.1136/annrheumdis-2021-eular.767

\section{AB0531 \\ THERAPIES FOR PERIPHERAL JOINT INVOLVEMENT IN PSORIATIC ARTHRITIS: A SYSTEMATIC LITERATURE REVIEW}

Y.Y. Leung ${ }^{1}$, T. Korotaeva ${ }^{2}$, L. Candia ${ }^{3}$, S. Juhl Pedersen ${ }^{4}$, W. Bautista-Molano ${ }^{5}$, E. Ruderman ${ }^{6}$, R. Bisoendial ${ }^{7}$, R. Perez Alamino ${ }^{8}$, W. Olsder ${ }^{9}$, B. Moeller $^{10}$, S. Grazio ${ }^{11}$, T. Gudu ${ }^{12}$, G. Mody ${ }^{13}$, C. Pineda ${ }^{14}$, H. Raffayova ${ }^{15}$, S. Rohekar ${ }^{16}$ O. Fitzgerald ${ }^{17}$ on behalf of GRAPPA treatment recommendations peripheral arthritis working group. ${ }^{1}$ Singapore General Hospital, Rheumatology \& Immunology, Singapore, Singapore; ${ }^{2}$ Russia, V.A. Nasonova Institute of Rheumatology, Moscow, Russian Federation; ${ }^{3}$ Universidad Juárez del Estado de Durango, Faculty of Medicine, Durango, Mexico; ${ }^{4}$ Rigshospitalet, Center for Rheumatology and Spine Diseases, Copenhagen, Denmark; ${ }^{5}$ Universidad el Bosque, University Hospital Fundación Santa Fe de Bogota, Bogotá, Colombia; ${ }^{6}$ Northwestern University Feinberg School of Medicine, Rheumatology, Chicago, United States of America; ${ }^{7}$ Maasstad hospital, Department of Rheumatology and Clinical immunology, Rotterdam, Netherlands; ${ }^{8} \mathrm{Hospital}$ Avellaneda, Rheumatology Section, Tucumán, Argentina; ${ }^{9}$ Patient Research Partner,., Eindhoven, Netherlands; ${ }^{10}$ Inselspital University Hospital Bern, Switzerland, Rheumatology \& Immunology, Bern, Switzerland; ${ }^{11}$ University Clinical Centre Sestre milosrdnice, Department for Rheumatology, Physical and Rehabilitation Medicine, Zagreb, Croatia; ${ }^{12}$ Cambridge University Hospitals NHS FT, Rheumatology, Cambridge, United Kingdom; ${ }^{13}$ University of KwaZuluNatal, Department of Rheuamtology, Durban, South Africa; ${ }^{14}$ Instituto Nacional de Rehabilitación Luis Guillermo Ibarra, Medicine and rehabilitation, Mexico City, Mexico; ${ }^{15}$ National Institute of Rheumatic Diseases,.., Piešlany, Slovakia (Slovak Republic); ${ }^{16}$ Western University, London, Ontario, Rheumatology, London, Canada; ${ }^{17}$ Conway Institute for Biomolecular Research, University College Dublin,., Dublin, Ireland

Background: Much new information has been reported since the last evidence-based GRAPPA recommendations for the treatment of psoriasis and psoriatic arthritis (PsA)

Objectives: We aimed to compile the evidence for the efficacy and safety of established and newly developed drugs targeting the peripheral arthritis domain in PsA so as to provide information for the revised GRAPPA treatment recommendations.

Methods: A working group consisting of clinicians and patient research partners (PRPs) was convened. We performed an updated systematic literature review (SLR) of randomized controlled trials (RCTs) for the treatment of PsA, including peripheral arthritis, from the date of the last GRAPPA SLR, from February 19, 2013 to August 28,2020 . The working group reviewed the evidence supporting the efficacy on peripheral arthritis for each class of drug, according to the Grading of Recommendations Assessment, Development, and Evaluation (GRADE) approach for three patients groups: 1) naïve to treatment; 2) refractory to conventional (-c) DMARDs; and 3) with prior biological (-b)DMARD experience. We also evaluated the evidence for non-pharmacological treatments. A set of important outcomes for the peripheral arthritis domain was assessed for each class of medication. The certainty of evidence supporting each class of drugs for each patient group was evaluated. Recommendations were derived through consensus meetings.

Results: 87 articles from 52 RCTs were included. For patients with mild disease who are naïve to treatment, the working group strongly recommends csDMARDs (methotrexate, sulfasalazine, leflunomide) and PDE4i, and weakly recommends them for severe disease, where TNFi are preferred over csDMARDs. Other bDMARDs (IL-17i, IL-12/23i, IL-23i) and JAKi are strongly recommended to treat peripheral arthritis for treatment naïve patients. For patients with inadequate response to csDMARDs, we strongly recommend TNFi, IL-17i, IL-12/23i, IL-23i and JAKi. For those who had prior experience with bDMARDs, 